\title{
DESENVOLVIMENTO PROFISSIONAL DOCENTE DE PROFESSORAS ALFABETIZADORAS EXPERIENTES: MARCAS POSITIVAS E NEGATIVAS VIVENCIADAS AO LONGO DA CARREIRA DOCENTE
}

\author{
Juliana Pedroso Bruns ${ }^{1}$, Rita Buzzi Rausch ${ }^{2}$ \\ ${ }^{1}$ Mestranda em Educação no Programa de Pós-Graduação em Educação da Universidade Regional de Blumenau \\ (PPGE/FURB). Bolsista CAPES. ORCID iD: https://orcid.org/0000-0002-9310-1892 E-mail: julianap.bruns@gmail.com \\ ${ }^{2}$ Doutora em Educação pela Universidade Estadual de Campinas - UNICAMP e Pós-doutorado em Educação junto à \\ Universidade Federal de Santa Catarina - UFSC. Professora visitante do PPGE da Universidade Regional de \\ Blumenau (FURB) e da Universidade da Região de Joinville (Univille). ORCID iD: https://orcid.org/0000-0002- \\ 9413-4848 E-mail: ritabuzzirausch@gmail.com
}

\section{RESUMO}

A presente pesquisa teve por objetivo desvelar as marcas positivas e negativas na trajetória docente de seis professoras alfabetizadoras experientes que atuam há mais de quinze anos na Rede Municipal de Ensino de Brusque (SC). A opção por professoras alfabetizadoras experientes, justifica-se pela trajetória já vivenciada por essas professoras no exercício de sua profissão. Como referencial teórico elegeu-se as contribuições de Marcelo García (1999, 2009), Vaillant e Marcelo (2012, 2015), Imbernón (2010, 2011), e Nóvoa (1992, 2000, 2009, 2010, 2019) para dialogar com as narrativas das professoras participantes. A pesquisa é de abordagem qualitativa e biográfica denominada "história de vida", e a análise dos dados ocorreu mediante a análise textual discursiva. Os resultados evidenciaram que as marcas positivas apontam para a formação e cursos oferecidos pelo município por meio do governo federal; o diálogo e a colaboração da família na relação do trabalho pedagógico; a relação com as crianças e a aprendizagem da leitura e da escrita. As marcas negativas revelam a falta de cursos destinados aos professores alfabetizadores; falta de formação continuada atrelada às reais necessidades dos professores; dificuldades com a família quando os pais duvidam do trabalho que realizam; inclusão na sala de aula e a falta de apoio dos familiares nesse processo. Espera-se, que as narrativas das professoras alfabetizadoras mais experientes, contribua para uma reflexão na formação de professores, auxiliando sobretudo, os professores alfabetizadores iniciantes na profissão. Palavras-chave: Desenvolvimento Profissional Docente. Professores Alfabetizadores Experientes. Formação de professores.

\section{PROFESSIONAL DEVELOPMENT TEACHER OF EXPERIENCED LITERACY TEACHERS: POSITIVE AND NEGATIVE BRANDS EXPERIENCED ALONG THE TEACHING CAREER}

\section{ABSTRACT}

The present research aimed to unveil the positive and negative marks in the teaching trajectory of six experienced literacy teachers who have worked for more than fifteen years in the Municipal Education Network of Brusque (SC). The option for experienced literacy teachers is justified by the trajectory already experienced by these teachers in the exercise of their profession. Contributions were chosen as a theoretical framework Marcelo García (1999, 2009), Vaillant and Marcelo (2012, 2015), Imbernón (2010, 2011), and Nóvoa $(1992,2000,2009,2010,2019)$ to dialogue with the narratives of the participating teachers. The research has a qualitative and biographical approach called "life story", and the data analysis occurred through discursive textual analysis. The results showed that the positive marks point to the training and courses offered by the municipality through the federal government; the dialogue and collaboration of the family in the relationship of pedagogical work; the relationship with children and learning to read and write. The negative marks reveal the lack of courses for literacy teachers; lack of continuing education linked to the real needs of teachers; difficulties with the family when the parents doubt the work they do; inclusion in the classroom and the lack of support from family members in this 
process. It is hoped that the narratives of the most experienced literacy teachers will contribute to a reflection on teacher training, helping, above all, literacy teachers beginning in the profession.

Keywords: Teacher Professional Development. Experienced Literacy Teachers. Teacher training.

\section{PROFESIONAL DE DESARROLLO PROFESIONAL PROFESORES DE ALFABETIZACIÓN CON EXPERIENCIA: MARCAS POSITIVAS Y NEGATIVAS EXPERIMENTADAS A LO LARGO DE LA CARRERA DOCENTE}

\section{RESUMEM}

La presente investigación tuvo como objetivo develar las marcas positivas y negativas en la trayectoria docente de seis alfabetizadores experimentados que han trabajado durante más de quince años en la Red Municipal de Educación de Brusque (SC). La opción por alfabetizadores experimentados se justifica por la trayectoria ya vivida por estos docentes en el ejercicio de su profesión. Se eligieron los aportes de marco teórico como Marcelo García (1999, 2009), Vaillant y Marcelo $(2012,2015)$, Imbernón $(2010,2011)$ y Nóvoa $(1992,2000,2009,2010,2019)$ para dialogar con las narrativas de los docentes participantes. La investigación tiene un enfoque cualitativo y biográfico denominado "historia de vida", y el análisis de datos se realizó a través del análisis textual discursivo. Los resultados mostraron que las calificaciones positivas apuntan a las capacitaciones y cursos que ofrece el municipio a través del gobierno federal; el diálogo y la colaboración de la familia en la relación del trabajo pedagógico; la relación con los niños y el aprendizaje de la lectura y la escritura. Las notas negativas revelan la falta de cursos para alfabetizadores; falta de formación continua vinculada a las necesidades reales de los profesores; dificultades con la familia cuando los padres dudan del trabajo que realizan; inclusión en el aula y la falta de apoyo de los familiares en este proceso. Se espera que las narrativas de los alfabetizadores más experimentados contribuyan a una reflexión sobre la formación del profesorado, ayudando, sobre todo, a los alfabetizadores que se inician en la profesión.

Palabras clave: Desarrollo profesional docente. Profesores de alfabetización experimentados. Formación de profesores.

\section{INTRODUÇÃO}

O desenvolvimento profissional docente, para Marcelo (2009) vem sendo tema de inúmeras investigações e revisões cujo o intuito é compreender este processo, e pode ser visto como uma construção, à medida que os docentes adquirem mais experiência, sabedoria e consciência profissional. Vaillant e Marcelo (2012) observam que este processo é contínuo e ocorre durante toda a trajetória profissional do professor, pois vive-se longe da época em que se pensava que os conhecimentos obtidos na formação inicial de professores, juntamente com - valor da experiência como fonte de aprendizado na prática, poderiam ser suficientes para concretizar o trabalho docente. Desse modo, as narrativas de professoras alfabetizadoras experientes elucidam percursos desse desenvolvimento profissional docente.

Imbernón (2011), observa a necessidade de aceitarmos que a docência é uma profissão, não para assumir privilégios contra ou "à frente" dos outros, mas para que mediante seu exercício, o conhecimento específico dos professores se coloque a serviço da mudança e da dignificação da pessoa, já que ser um profissional da educação significa participar da emancipação das pessoas. O objetivo da educação é, portanto, ajudar a tornar as pessoas mais livres, menos subordinadas do poder econômico, político e social. E a profissão de ensinar tem essa obrigação inerente. Nesse viés, ao conceber à docência como uma profissão, poder-se-á afirmar que cada docente é um profissional dotado de conhecimentos e saberes específicos que precisa ser valorizado e "ouvido" em sua narrativa singular.

$\mathrm{Na}$ presente pesquisa, busca-se justamente valorizar a singularidade presente nas narrativas docentes e, por meio dessas narrativas, objetiva-se desvelar as marcas positivas e negativas que seis professoras ${ }^{1}$

\footnotetext{
${ }^{1}$ Expõe-se ao leitor que, utiliza-se "professoras alfabetizadoras" no feminino, pois todas as professoras alfabetizadoras participantes desta pesquisa são mulheres e, utiliza-se "professores alfabetizadores", pois considera-se que também existem professores de alfabetização no gênero masculino. Desse modo, quando refere-se aos "professores alfabetizadores", faz-se alusão tanto ao gênero feminino, quanto ao gênero masculino.
} 
alfabetizadoras experientes efetivas, mediante concurso público que já tenham lecionado quinze anos ou mais na alfabetização e que atuam na Rede Municipal de Ensino de Brusque (SC), vivenciaram ao longo de suas trajetórias docentes, pois infere-se, que por meio de narrativas autobiográficas, elas poderão contribuir com o desenvolvimento profissional docente principalmente de professores alfabetizadores iniciantes na profissão, ao compartilharem suas experiências. Nesta pesquisa, entende-se que as marcas positivas seriam as vivências e/ou experiências, os prazeres, as alegrias, os sucessos e os momentos bem-sucedidos que as professoras alfabetizadoras participantes vivenciaram no decorrer de suas trajetórias. $E$, as marcas negativas representam o oposto, ou seja, as vivências e/ou experiências negativas e dificuldades vivenciadas na profissão de alfabetizadora.

A opção por professoras alfabetizadoras experientes justifica-se pela experiência que essas professoras trazem consigo em sua trajetória enquanto docentes. Ao mesmo tempo, infere-se que as professoras, ao narrarem suas experiências poderão contribuir com a formação docente, sobretudo, dos professores alfabetizadores iniciantes. A escolha por professoras efetivas mediante concurso público e não por professoras admitidas em caráter temporário (ACT), justifica-se pela compreensão de que muitas professoras ACT não permanecem após o término do ano letivo necessariamente com a mesma turma ou na mesma escola, e que por esse motivo, as professoras efetivas podem criar "laços mais profundos" com a comunidade em que lecionam por vários anos, servindo de referência para o meio em que atuam.

Destaca-se que com vistas a assegurar os aspectos éticos da pesquisa, que envolve a conduta das pesquisadoras em relação ao fato pesquisado e a dignidade humana de cada participante, a mesma encontra-se resguardada eticamente sob o Certificado de Apresentação para Apreciação Ética (Caae) número 22928619.5.0000.5370 aprovado pelo Comitê de Ética e Pesquisa (CEP) por meio da submissão na Plataforma Brasil.

Observa-se ainda que, o desenvolvimento profissional docente dos professores tem sido foco de atenção de estudiosos da área educacional, destacando-se dentre outros os trabalhos de Marcelo García (1999, 2009),
Vaillant e Marcelo (2012, 2015), Imbernón (2010, 2011) e Nóvoa (1992, 2000, 2009, 2010, 2019) que serviram de referência para a elaboração desse artigo.

A seguir, apresenta-se o delineamento metodológico utilizado no desenvolvimento desta pesquisa. Posteriormente, elucida-se a respeito do desenvolvimento profissional docente. Por fim, apresenta-se a análise dos resultados da pesquisa, explicitada em cinco categorias de análise, seguido das considerações finais.

\section{DELINEAMENTO METODOLÓGICO}

Para a presente pesquisa definiu-se como tipologia de investigação qualitativa e biográfica denominada "história de vida", a qual "pretende atribuir à subjetividade um valor de conhecimento" (FERRAROTTI, 2010, p. 36). Desse tipo de método extraem-se elementos, hipóteses, problemas e informações. Nóvoa (2010, p. 166167) observa que "as histórias de vida e o método (auto)biográfico ${ }^{2}$ integram-se no movimento atual que procura repensar as questões da formação, acentuando a ideia que "ninguém forma ninguém" e que a "formação é inevitavelmente um trabalho de reflexão sobre os percursos da vida".

Os instrumentos utilizados para a geração de dados desta pesquisa foram a escrita de carta pessoal e entrevista narrativa. A entrevista narrativa foi realizada pelo aplicativo "WhatsApp" com mensagens de áudio, devido a "pandemia causada pelo coronavírus", pois, as aulas presenciais foram suspensas por meio da Portaria no 343, de 17 de março de 2020 em caráter excepcional, por aulas que utilizem meios e tecnologias de informação e comunicação, nos limites estabelecidos pela legislação em vigor (BRASIL, 2020a). Além disso, foi decretado no país estado de calamidade pública nos termos da solicitação do Presidente da República encaminhada por meio da Mensagem no 93, de 18 de março de 2020 (BRASIL, 2020b).

Com relação às cartas, a primeira pesquisadora expõe, que primeiramente escreveu uma carta e entregou pessoalmente às professoras alfabetizadoras em suas respectivas escolas e apresentou-se. Nessa carta ela se colocou como professora alfabetizadora iniciante, pois por certo, encontra-se nessa posição. Diante disso, por meio da escrita da carta pessoal contou às professoras alfabetizadoras experientes seu

\footnotetext{
${ }^{2}$ Grifos no original.
} 
percurso identitário de formação inicial e também convidou as professoras alfabetizadoras experientes a escrevem uma carta (respondendo a primeira pesquisadora) se apresentando e contando também percursos de seu desenvolvimento profissional docente enquanto professora alfabetizadora experiente.

Optou-se primeiramente por utilizar o gênero carta como meio de gerar os dados da pesquisa, pois considera-se que escrever e refletir sobre a própria história de vida é uma experiência que pode transformar a prática pedagógica do professor, na qual possibilita a busca por memórias de si, e por meio dessas memórias o narrador passa a compreender a si mesmo e a ressignificar a sua própria prática docente, pois, como observam Prado e Soligo (2007, p. 46) “[...] é necessária a reflexão sobre a prática profissional e se escrever favorece o pensamento reflexivo, a conclusão acaba por ser inevitável: a produção de textos escritos é uma ferramenta valiosa na formação de todos".

Num segundo momento da pesquisa, foi realizada uma entrevista narrativa com cinco $^{3}$ professoras alfabetizadoras que se propuseram a escrever a carta. A entrevista narrativa complementou a escrita da carta pessoal das professoras alfabetizadoras experientes, sendo que posteriormente foi realizado juntamente a análise dos dados gerados a partir dos dois instrumentos por meio da Análise Textual Discursiva (ATD). Prado e Soligo (2007, p. 48) expõem que as narrativas possibilitam o registro de partilhas e histórias e que elas supõem

[...] uma sequência de acontecimentos, é um tipo de discurso que nos presenteia com a possibilidade de dar à luz 0 nosso desejo de os revelar. Podemos dizer que a narrativa comporta dois aspectos essenciais: uma sequência de acontecimentos e uma valorização implícita dos acontecimentos relatados. E o que é particularmente interessante são as muitas direções que comunicam

\footnotetext{
${ }^{3}$ Das seis participantes que escreveram a carta, uma professora optou por não realizar a entrevista narrativa, mas se colocou à disposição para complementar e/ou sanar possíveis dúvidas que surgissem no decorrer da pesquisa. E uma professora, optou por realizar a entrevista dialogando por meio da escrita textual (ao invés de dialogar com mensagens de áudio).
}

as suas partes com o todo. Os acontecimentos narrados de uma história tomam do todo os seus significados. Porém, o todo narrado é algo que se constrói a partir das partes escolhidas. Essa relação entre a narrativa e o que nela se revela faz com que suscite interpretações e não explicações - não é o que se explica que conta, mas sim, o que se pode interpretar (PRADO; SOLIGO, 2007, p. 48).

Expõe-se, portanto, que na entrevista narrativa não existe um roteiro pré-estruturado, com perguntas pré-definidas pelas pesquisadoras, pois ela considera a profundidade que emerge a partir das histórias de vida e formação das entrevistadas.

Ressalta-se, que a interpretação e análise dos dados foi realizada mediante a análise textual discursiva (ATD). Moraes e Galiazzi (2011) compreendem esse procedimento como "uma tempestade de luz" que possibilita a compreensão dos dados por meio desta análise. Nesse processo, discorrem sobre a composição de um ciclo, organizado mediante os seguintes elementos:

1 - Desmontagem dos textos: também denominado de processo de unitarização, implica examinar os textos em seus detalhes, fragmentando-os no sentido de atingir unidades constituintes, enunciados referentes aos fenômenos estudados.

2 - Estabelecimento de relações: este processo denominado de categorização envolve construir relações entre as unidades de base, combinando-as e classificando-as, reunindo esses elementos unitários na formação de conjuntos que congregam elementos próximos, resultando daí sistemas de categorias.

3 - Captando o novo emergente: a intensa 


\begin{abstract}
impregnação nos materiais da análise desencadeada nos dois focos anteriores possibilita a emergência de uma compreensão renovada do todo. O investimento na comunicação dessa nova compreensão, assim como de sua crítica e validação, constitui o último elemento do ciclo de análise proposto. $\mathrm{O}$ metatexto resultante desse processo representa um esforço de explicitar a compreensão que se apresenta como produto de uma nova combinação dos elementos construídos ao longo dos passos anteriores (MORAES; GALIAZZI, 2011, p. 11-12).
\end{abstract}

A exposição segue tendo como foco o ciclo como um todo, aproximando-o de sistemas complexos e auto-organizados:

4 - um processo autoorganizado: o ciclo de análise, ainda que composto de elementos racionalizados e em certa medida planejados, em seu todo pode ser compreendido como um processo auto-organizado do qual emergem novas compreensões. Os resultados finais, criativos e originais, não podem ser previstos. Mesmo assim, é essencial o esforço de preparação e impregnação para que a emergência do novo possa concretizar-se (MORAES; GALIAZZI, 2011, p. 12).

Diante dos elementos expostos anteriormente, corroborando com os autores Moraes e Galliazi (2011), a análise textual discursiva pode ser compreendida como um processo auto-organizado de construção de compreensão em que novos entendimentos surgem a partir de um seguimento recursivo de três componentes: a desconstrução dos textos do "corpus", a unitarização; o estabelecimento de relações entre os dados unitários, a categorização; o apreender o emergente em que a nova compreensão é informada e legitimada.

No processo de unitarização, observa-se que o "corpus" são as cartas pessoais e as entrevistas narrativas das professoras alfabetizadoras experientes, que foram analisadas e separadas por similaridade com base na categoria a priori proveniente do seguinte objetivo desta pesquisa: desvelar as marcas positivas e negativas que seis professoras alfabetizadoras experientes que atuam na Rede Municipal de Ensino de Brusque (SC) vivenciaram no decorrer de suas trajetórias docentes.

Sendo assim, após realizado o processo de unitarização, expõe-se que as categorias emergentes surgiram com base nas unidades de sentido estabelecidas provenientes da reunião das cartas pessoais e entrevistas narrativas. Deste modo, para melhor esclarecimento do processo realizado, elucida-se no quadro abaixo a categoria a priori, os instrumentos utilizados para unitarização das unidades de sentido e as categorias emergentes provenientes da análise dos dados mediante a ATD que serão desveladas mais adiante na análise dos dados da pesquisa. 
Quadro 01. Categoria a priori, unidades de sentido e categorias emergentes:

\begin{tabular}{|c|c|c|}
\hline Categoria a priori & Unidades de sentido & Categorias emergentes \\
\hline $\begin{array}{l}\text { Desenvolvimento profissional } \\
\text { docente: marcas positivas e } \\
\text { negativas ao longo da carreira }\end{array}$ & $\begin{array}{l}\text { Cartas pessoais; } \\
\text { Entrevista Narrativa }\end{array}$ & $\begin{array}{c}1 \text { Marcas positivas da formação } \\
\text { continuada: eu tive muitos cursos } \\
\text { bons que me acompanharam } \\
\text { durante a vida; } \\
2 \text { Marcas negativas da formação } \\
\text { continuada: a gente tem a formação } \\
\text { continuada, mas a gente sabe que } \\
\text { às vezes é mais para cumprir uma } \\
\text { obrigação; } \\
3 \text { Marcas positivas na relação família } \\
\text { e escola: eu sempre tive conversas } \\
\text { francas e sinceras; } \\
4 \text { Marcas negativas na relação } \\
\text { família e escola: o desafio é com os } \\
\text { pais e trabalhar com as crianças } \\
\text { especiais; } \\
5 \text { Marcas positivas na relação com } \\
\text { as crianças: o meu maior prazer é } \\
\text { ver e escutar meus alunos lendo } \\
\text { para mim; }\end{array}$ \\
\hline
\end{tabular}

Fonte: As autoras.

Destaca-se que as categorias de análise foram definidas por meio de excertos das cartas das participantes e por meio das entrevistas narrativas. No que diz respeito à identificação das participantes, a pesquisadora é identificada com a letra $\mathrm{P}$ e as professoras participantes foram identificadas pelos respectivos nomes, conforme acordado antecipadamente com ambas, seguidos das letras P1, P2, P3, e assim sucessivamente até P6. Além disso, as narrativas das professoras estarão grifadas em itálico, para melhor destaque no texto. No quadro de número 02 , apresenta-se - perfil das professoras alfabetizadoras participantes da pesquisa.

Quadro 02. Perfil das Professoras Alfabetizadoras experientes da Rede Municipal de Ensino de Brusque participantes da pesquisa.

\begin{tabular}{|c|c|c|c|c|}
\hline PROFESSORAS & MAGISTÉRIO & GRADUAÇÃO & $\begin{array}{c}\text { Especialização } \\
\text { (Lato Sensu) }\end{array}$ & IDADE \\
\hline Nice & Sim & Pedagogia & Séries Iniciais & 68 anos \\
\hline Claudia & Sim & Pedagogia & $\begin{array}{c}\text { Séries Iniciais e } \\
\text { Educação Infantil; } \\
\text { Gestão Escolar }\end{array}$ & 45 anos \\
\hline Gésica & Não & Pedagogia & Psicopedagogia & 39 anos \\
\hline Rute & Sim & Pedagogia & $\begin{array}{c}\text { Séries Iniciais e } \\
\text { Educação Infantil }\end{array}$ & 60 anos \\
\hline Cilene & Sim & Pedagogia & Administração Escolar & 57 anos \\
\hline Claudinice & Sim & Pedagogia & Desenvolvimento da & 51 anos \\
\hline
\end{tabular}

Fonte: As autoras.

Observa-se que com base nas informações contidas no quadro 2 , em relação aos aspectos pessoais das participantes investigadas, todas são do gênero feminino, totalizando 06 professoras alfabetizadoras com idade entre 39 e 68 anos.
Dentre as participantes, encontra-se os seguintes níveis de titulação: apenas uma, das seis participantes não cursou o magistério. Todas as professoras possuem licenciatura em Pedagogia e especialização lato sensu. 
No quadro a seguir, apresenta-se

professoras participantes da pesquisa. aspectos referentes à atuação profissional das

Quadro 03. Atuação profissional das professoras alfabetizadoras experientes da Rede Municipal de Ensino de Brusque participantes da pesquisa.

\begin{tabular}{|c|c|c|c|}
\hline PROFESSORAS & $\begin{array}{c}\text { HORAS AULA DE } \\
\text { TRABALHO }\end{array}$ & $\begin{array}{c}\text { TEMPO DE SERVIÇO } \\
\text { NA EDUCAÇÃO }\end{array}$ & $\begin{array}{c}\text { TEMPO DE DOCENTE } \\
\text { NA ALFABETIZAÇÃO }\end{array}$ \\
\hline Nice & $\begin{array}{c}\text { Aposentada } \\
\text { (Em serviço) } \\
20 h\end{array}$ & 51 anos & Entre 15 a 20 anos $^{4}$ \\
\hline Claudia & $40 h$ & 24 anos & 18 anos \\
\hline Gésica & $40 h$ & $14^{5}$ anos & 18 anos \\
\hline Rute & $40 h$ & 28 anos & 16 anos \\
\hline Cilene & $\begin{array}{c}\text { Aposentada (Em } \\
\text { serviço) } \\
40 h\end{array}$ & 31 anos & 25 anos \\
\hline Claudinice & Aposentada & 27 anos & \\
\hline
\end{tabular}

Fonte: As autoras.

\footnotetext{
${ }^{4}$ A professora não soube dizer com precisão o seu tempo na alfabetização, informando que estava entre 15 a 20 anos.

${ }^{5}$ A participação desta professora, justifica-se pelo gestor ter informado que ela possuía 15 anos e que, no momento em que estive na respectiva escola, a mesma professora demonstrou um grande desejo e contentamento em participar desta pesquisa. Além disso, enquanto docente ela possui 18 anos, e na alfabetização está quase completando 15 anos.
} 
Quanto à carga horária, apenas a professora Nice e a professora Cilene já estão aposentadas, mas continuam trabalhando na educação. A professora Nice trabalha 20h semanais como professora regente e a professora Cilene trabalha $40 \mathrm{~h}$ semanais como coordenadora pedagógica. As demais professoras trabalham 40h semanais, com exceção da professora Claudinice que está aposentada pela Rede Municipal de Ensino de Brusque e no momento não está exercendo à docência.

Apenas uma professora não possui no mínimo 15 anos de experiência na alfabetização, conforme justificado anteriormente.

Elucida-se ainda que os critérios de seleção dos participantes desta pesquisa foram: a) Ser professor alfabetizador que já tenha no mínimo 15 anos de experiência como docente no ciclo de alfabetização; b) Pertencer a relação de Professores concursados fornecida pela Secretaria de Administração e Secretaria da Educação da Prefeitura Municipal de Brusque (SC).

Esclarecido 0 delineamento metodológico, na seguinte seção reflete-se a respeito do desenvolvimento profissional docente.

\section{DESENVOLVIMENTO PROFISSIONAL DOCENTE}

Para dialogar sobre o desenvolvimento profissional docente encontra-se respaldo em García (1999) quando este observa que tal concepção, adota o professor como um profissional de ensino, no qual o conceito de "desenvolvimento" assume a conotação de evolução e continuidade que parece superar a tradicional justaposição entre a formação inicial e o aperfeiçoamento dos professores, pressupondo uma abordagem na formação de professores que valorize o seu caráter contextual, organizacional e orientado para a mudança. Desse modo, García (1999) observa que o desenvolvimento profissional dos professores está diretamente relacionado com a melhoria das suas condições de trabalho, com a possibilidade institucional de maiores índices de autonomia e capacidade de ação dos professores no individual e no coletivo, sendo necessário, ligar o desenvolvimento profissional dos professores com as fases da carreira docente, conforme pode ser observado mais detalhadamente por Vaillant e Marcelo (2015) no livro "El ABC, y D de LA Formación Docente". A seguir, elucida-se cada etapa da carreira docente conforme exposto pelos autores:

Etapa A - de Antecedentes: Esse período é caracterizado pela etapa prévia do ofício de ensinar. Os aspirantes a docentes trazem consigo uma série de crenças e imagens baseadas em suas próprias experiências que influenciam a forma como enfrentam a complexa tarefa de dar aula. (VAILLANT; MARCELO, 2015).

Etapa B - de Base: Esse período é caracterizado pela fase de formação inicial do docente, que ao longo da história vem sendo desempenhada por instituições específicas, por um pessoal especializado e mediante um currículo que institui a sequência e o conteúdo instrucional do programa formativo (VAILLANT; MARCELO, 2015).

Etapa C - de Começo: Essa fase é caracterizada pelos primeiros anos de vida profissional do professor. Nessa etapa importante de aprender a ensinar, os docentes formados ingressam nas escolas como docentes iniciantes. Essa fase inclui medidas de apoio e supervisão, além de uma avaliação formal para certificar a obtenção de habilidades sem as quais os docentes não poderiam acessar a profissão (VAILLANT; MARCELO, 2015).

Etapa D - de Desenvolvimento: Essa fase é caracterizada pelo desenvolvimento profissional contínuo do docente. Muitos termos têm sido utilizados para falar de desenvolvimento profissional, como formação contínua, formação em serviço, ou formação permanente (VAILLANT; MARCELO, 2015). Desse modo, ao falar sobre a profissionalidade docente, considera-se imprescindível destacar a formação docente aqui empregada numa perspectiva "contínua", conforme observam os autores supracitados, ou seja, uma formação ao longo da vida que não se extenua nas experiências que antecedem a formação inicial e a formação ocorrida na universidade. Mas, como destaca Imbernón (2010), deve valorizar a identidade docente do professor e isso requer valorizar toda a sua subjetividade e o seu percurso profissional docente.

Entretanto, apesar da importância que o desenvolvimento profissional dos professores tem, tanto para o professor quanto para a qualidade do ensino e aprendizagem dos estudantes, Vaillant e Marcelo (2012) observam que a tradição tem apontado um tipo de desenvolvimento profissional marcado pelo 
banimento das necessidades dos professores, estudantes e escolas, sem levar em conta as fases do desenvolvimento profissional e as reais necessidades dos docentes. A maior parte das atividades de educação continuada para professores são eventos esporádicos, e não experiências evolutivas de aprendizado. Essas atividades tendem a ser intelectualmente superficiais, desmembradas dos temas profundos do currículo e da aprendizagem dos estudantes e na maioria das vezes são fragmentadas e não cumulativas. Os temas são determinados por outras pessoas que não os destinatários e não levam em consideração o que sabemos sobre como aprender.

Nesse viés, tendo em vista superar o caráter tradicionalmente individualista na profissão, corrobora-se com Imbernón (2011) quando este observa, que a formação assume um papel que se transforma na possibilidade de criar espaços de participação, reflexão e formação para que os docentes aprendam e se adaptem para conviver com a mudança e a incerteza, o que implica em uma formação docente colaborativa ocorrida no interior da escola juntamente com os demais profissionais da mesma instituição. Nesse movimento de partilha, pressupõe-se um desenvolvimento da reflexão docente no coletivo, o que contribuiria para abrir caminhos para a autonomia profissional compartilhada, já que a profissão docente conforme expõe Imbernón (2010), deveria compartilhar seu conhecimento com os demais profissionais que atuam no mesmo espaço institucional. Além disso, Nóvoa (1992, p. 27) igualmente observa que "práticas de formação que tomem como referência as dimensões coletivas contribuem para a emancipação profissional e para a consolidação de uma profissão que é autônoma na produção dos seus saberes e dos seus valores".

Imbernón (2010), observa que nesse percurso, faz-se importante valorizar as narrativas dos professores à ética da formação continuada, nas quais as experiências pessoais dos professores relacionam-se às tarefas profissionais, já que o ensino requer uma implicação pessoal. Ou ainda, como observa Nóvoa (2009), o professor é a pessoa e a pessoa é o professor, destacando a necessidade de construir uma teoria da pessoalidade dentro de uma teoria da profissionalidade docente ao expor que a formação não se constrói por acumulação de cursos ou técnicas, mas sim por meio de um trabalho reflexivo e crítico sobre a prática e de uma (re)construção permanente de uma identidade pessoal. Por isso, é tão importante investir na pessoa do professor e dar um estatuto ao saber da experiência (NÓVOA, 1992).

Tais dizeres, reafirma a posição das pesquisadoras nesta pesquisa, pois valoriza as narrativas provenientes das histórias de vida das professoras alfabetizadoras experientes, especialmente porque compreende-se que a partir de seus dizeres, de suas experiências enquanto docentes, elas poderão contribuir para a formação docente colaborativa, na medida em que compartilham seus conhecimentos enquanto alfabetizadoras experientes. Nesse sentido, a presente pesquisa valoriza esse tipo de formação, construída dentro da profissão, na qual, sobretudo, sugere o compartilhamento das "alegrias e as penas", conforme destacou Imbernón (2010), desse percurso de constituição identitária. Ou conforme será elucidado nesta pesquisa, "as marcas positivas e as negativas" da profissão. Além disso, ao compartilhar suas experiências, o professor poderá refletir sobre sua prática docente e nessa reflexão poderá ressignificá-la, assumindo para si a responsabilidade do seu próprio desenvolvimento profissional, tornando-se protagonista da sua formação (NÓVOA, 1992). Nessa direção, Nóvoa (2009) observa que o registro escrito, tanto das vivências pessoais como das práticas dos professores, é essencial para que cada um tenha uma maior clareza do seu trabalho e da sua identidade como professor. Deste modo, a formação deve colaborar para criar nos futuros professores hábitos de reflexão e de autorreflexão que são fundamentais numa profissão que não se extenua em matrizes científicas ou pedagógicas, e que se define, decisivamente, a partir de referências pessoais.

Nóvoa $(2000$, p. 16) igualmente nos traz ainda importantes contribuições acerca da profissionalidade docente e aponta que o processo identitário dos professores leva os três "AAA" - "A de Adesão, A de Ação, A de Autoconsciência",

A de Adesão, porque ser professor implica sempre a adesão a princípios e a valores, a adoção de projetos, um investimento positivo nas potencialidades das crianças e dos jovens. - A de Ação, porque também 
aqui, na escolha das melhores maneiras de agir, se jogam decisões do foro profissional e do foro pessoal. Todos sabemos que certas técnicas e métodos "colam" melhor com a nossa maneira de ser do que outros. Todos sabemos que o sucesso ou o insucesso de certas experiências "marcam" a nossa postura pedagógica, fazendo-nos sentir bem ou mal com esta ou aquela maneira de trabalhar na sala de aula. - A de Autoconsciência, porque em última análise tudo se decide no processo de reflexão que o professor leva a cabo sobre a sua própria ação. É uma dimensão decisiva da profissão docente, na medida em que a mudança e a inovação pedagógica estão intimamente dependentes deste pensamento reflexivo. (NÓVOA, 2000, p. 16).

Para o autor, a identidade docente não é um dado adquirido, não é uma propriedade, não é um produto. A identidade é um espaço de lutas e de conflitos, é um lugar de construção de formas de ser e de estar na profissão docente. Por isso, é mais apropriado falar em processo identitário, destacando a combinação dinâmica que caracteriza a maneira como cada um se sente e se diz professor (NÓVOA, 2000). Essa construção identitária, perpassa o desenvolvimento profissional dos professores que ocorre ao longo de toda a trajetória docente, tal processo é comumente marcado por "marcas positivas e negativas", marcas essas, que poderão ser visualizadas a seguir nas narrativas das seis professoras participantes desta pesquisa, mediante a análise dos dados provenientes da escrita da carta pessoal e da entrevista narrativa, emergidas em cinco categorias emergentes de análise, por meio da análise textual discursiva.

\section{MARCAS POSITIVAS DA FORMAÇÃO CONTINUADA: EU TIVE MUITOS CURSOS BONS QUE ME ACOMPANHARAM DURANTE A VIDA}

Inicia-se a presente reflexão, desvelando as marcas positivas da formação continuada narradas pelas professoras alfabetizadoras participantes da pesquisa. Marcas que perpassam experiências vividas em cursos e/ou programas de formação continuada ao longo de suas experiências profissionais. Para tal, inicia-se esta categoria de análise, com a narrativa da professora Nice ${ }^{\mathrm{P} 1}$ quando ela rememora seu percurso formativo no decorrer dos seus 51 anos de docência. Nessa caminhada, ela observa que ao longo do tempo, teve muitos cursos direcionados para professores alfabetizadores, mas que no momento ela não lembrava os nomes" ${ }^{\mathrm{P}}$, "tinha sempre assim né... dependia da época, então, eram cursos muito bons ${ }^{p 1 "}$.

Do mesmo modo, a professora Claudia ${ }^{\mathrm{P} 2}$ ao relembrar os cursos de formação ofertados pelo município, expõe: "a gente também teve muitos cursos na área da alfabetização, na época, eu acho que em 2002, 2003, eu tive o PROFA, foram dois ou três anos. Depois eu tive esse PNAIC, que eu digo que não foi um curso, já fiz Mestrado, foram quatro anos que fiz esse PNAIC. Então, muita coisa a gente aprendeu, muita! Então, a gente tem muita coisa ao longo desse tempo né, que só tem a acrescentar, pra vida profissional e pro pessoal da gente ${ }^{\mathrm{P2} "}$.

$\mathrm{Na}$ fala da professora Claudia ${ }^{\mathrm{P} 2}$, observase a relação que a professora ${ }^{\mathrm{P2}}$ faz acerca da formação continuada vivenciada e sua contribuição para a "vida profissional e pessoal P2", sendo impossível não relacioná-la, portanto, com os dizeres de Nóvoa (2009, p. 39), quando ele observa que a formação de professores precisa reforçar "a pessoa-professor e o professor pessoa", o que implica, conceber a dimensão humana presente na profissão docente, reforçando que os professores sejam pessoas inteiras.

Expõe-se que o PROFA "Programa de Formação de Professores Alfabetizadores" mencionado acima pela professora Claudia ${ }^{\mathrm{P2}}$, foi lançado em 2000 e seu objetivo era proporcionar novas técnicas de alfabetização provenientes de estudos realizados por educadores de diversos países. Tais estudos tinham como base as mudanças ocorridas nas práticas de ensino da leitura e da escrita sucedidas a partir de 1985 com as pesquisas de Emília Ferreiro e Ana Teberoski e a publicação da obra Psicogênese da 
Língua Escrita (MENEZES; SANTOS, 2001). Já, o PNAIC "Pacto Nacional pela Alfabetização na Idade Certa" foi promulgado em 4 de julho de 2012, a partir da Portaria no 867, e se consolidou como um Programa de Formação Continuada para Alfabetizadores (BRASIL, 2012), cujo objetivo foi assegurar que todas as crianças estivessem alfabetizadas até os 8 anos de idade, ao final do 3ㅇano do Ensino Fundamental.

Já a professora Claudinice ${ }^{\mathrm{P} 6}$ relembra com carinho seu percurso profissional docente ao narrar: "muitos estudiosos da educação foram vistos como, Jean Piaget, Vygotsky, Decroly, Emília Ferreiro, Paulo Freire, Freinet, Maria Montessori, Wallon entre muitos outros, que fizeram parte do meu caminhar pelo ensino médio, o magistério, pedagogia, especialização, cursos de capacitação ${ }^{P 6 \prime \prime}$.

Igualmente a professora Gésica ${ }^{\mathrm{P3}}$, ao rememorar os cursos de formação continuada oferecidos pelo município, expõe "eu vejo assim, que o município, ao longo desse tempo que tenho na alfabetização, tanto o município como a nível de Brasil, estão sempre tentando é [...] ter formação e propiciar conhecimento melhor pro professor né. Mas, a professora Gésica ${ }^{\mathrm{P}}$ complementa sua narrativa, expondo, "mas ainda falta! Nossa, mas eles não deixam de dar aquele acesso pra gente né!"

Nas narrativas das professoras já mencionadas, reflete-se que, embora as professoras tenham exposto que no município há momentos de formação, "ainda falta ${ }^{P 3 "}$... sendo visíveis, portanto, algumas "lacunas" presentes nas formações fornecidas às professoras. A esse respeito, Nóvoa (2009, p. 23) expõe que "muitos programas de formação contínua têm-se revelado inúteis, servindo apenas para complicar um cotidiano docente já de si fortemente exigente", sendo necessário, portanto, recusar o consumismo de cursos que não vão ao encontro das reais necessidades dos professores, mas que caracteriza o atual mercado da formação que é continuamente "alimentado" por um sentimento de desatualização na profissão.

Expõe-se que algumas das dificuldades; necessidades e angústias enfrentadas pelas alfabetizadoras ficaram explícitas e implícitas nas narrativas que serão desveladas na categoria de análise a seguir, quando elas rememoram as "marcas negativas" que vivenciaram e/ou vivenciam na formação continuada enquanto professoras alfabetizadoras.

\section{MARCAS NEGATIVAS DA FORMAÇÃO CONTINUADA: A GENTE TEM A FORMAÇÃO CONTINUADA, MAS A GENTE SABE QUE ÀS VEZES É MAIS PARA CUMPRIR UMA OBRIGAÇÃO}

Nesta categoria de análise, desvela-se as marcas negativas que estiveram presentes nas narrativas das professoras alfabetizadoras quando rememoraram acerca dos cursos; programas e/ou prêmios que elas vivenciaram (ou não) ao longo de suas experiências profissionais enquanto professoras alfabetizadoras. Para tal, inicia-se esta categoria de análise, com a narrativa da professora Nice ${ }^{\mathrm{P} 1}$ que expõe: "deveria ter cursos para professores de 1 o ano. A gente tem a formação continuada, mas a gente sabe que às vezes é mais para cumprir uma obrigação que a prefeitura tem de fazer essa formação continuada ${ }^{P 1 "}$.

$\mathrm{Na}$ narrativa da professora Nice ${ }^{\mathrm{P} 1}$ chamase a atenção, para a questão da formação que por vezes distancia-se do local de trabalho dos docentes, e que muitos autores já vêm atentando sobre a importância de uma formação centrada no ambiente profissional do professor, ou seja, na escola. Imbernón (2011) expõe que a formação centrada na escola, envolve todas as estratégias empregadas conjuntamente pelos professores e formadores de modo a responder às necessidades definidas da escola e elevar a qualidade do ensino e aprendizagem dos estudantes. Do mesmo modo, quando se fala em formação centrada na escola, entende-se que ela se transforma em local de formação prioritária diante de outras ações formativas, sendo assim, ela é mais que uma simples mudança de lugar da formação. Os programas de formação continuada devem ser delineados, portanto, para mobilizar os docentes a trabalharem coletivamente, promovendo mudanças nas escolas que atendam cada vez melhor às necessidades dos estudantes. As tarefas de melhoria da escola têm que ser realizadas pelo coletivo, em um processo de interação, de trocas, de colaboração.

Gésica $^{\mathrm{P3}}$, ao narrar percursos do seu desenvolvimento profissional docente, observa uma situação que em sua percepção é algo negativo, pois há um tempo foi comentado que os professores alfabetizadores deveriam receber um abono enquanto professor alfabetizador, nas palavras da professora, "o professor alfabetizador tem aquele prêmio né, isso ali o município não dá pra gente, entende? Isso ali é uma coisa que falta assim, é negativo né! Então, positivamente, eles até passam uma demanda de formações né, isso 
é o positivo, mas negativo ao mesmo tempo...". Igualmente, a professora Rute ${ }^{\mathrm{P} 4}$ expõe, "era para ganharmos uma gratificação anual do município, aquele prêmio professor alfabetizador, uma época foi falado que iríamos ganhar, mas não ganhamos".

Com relação ao prêmio mencionado pela professora Gésica $^{\mathrm{P} 3}$, expõe-se que o mesmo, consta no Estatuto do Magistério Público Municipal de Brusque - (SC) cidade em que a pesquisa foi realizada, e destina-se, sobretudo, aos servidores efetivos. O capítulo IV do Estatuto, destina-se a "Gratificações e Prêmios", e em seu Art. 87, consta no inciso III - Prêmio ao Professor Alfabetizador. Mais adiante, na seção III intitulada "Do Prêmio ao Professor Alfabetizador", lê-se com maiores detalhes no Art. 96:

$$
\begin{aligned}
& \text { Aos professores que } \\
& \text { atuam em classes/turmas } \\
& \text { de alfabetização conceder- } \\
& \text { se-á, anualmente, prêmio } \\
& \text { equivalente a quinze por } \\
& \text { cento do valor do padrão } \\
& \text { de vencimento "A" do } \\
& \text { respectivo nível de } \\
& \text { habilitação, condicionado } \\
& \text { ao desempenho e sucesso } \\
& \text { dos educandos no } \\
& \text { processo de letramento e } \\
& \text { alfabetização, de acordo } \\
& \text { com regulamentação } \\
& \text { própria na Proposta de } \\
& \text { Alfabetização elaborada } \\
& \text { Letramento elabora de } \\
& \text { pela Secretaria dela } \\
& \text { Educação (BRUSQUE, } \\
& \text { 2009, p. 28). }
\end{aligned}
$$

Do mesmo modo, a professora Nice ${ }^{\mathrm{P} 1}$, expõe que os professores alfabetizadores deveriam receber esse prêmio e reflete: "até uma época foi comentada essa possibilidade, mas não colocou-se na prática... de um professor alfabetizador receber uma gratificação ${ }^{\mathrm{P}}$, aí não precisaria ser nem só do 10 ano, mas talvez até do $2^{\circ}$ ano, não sei se até do $3 \circ$, mas 10 e $2 \%$... deveria receber um abono como professor alfabetizador. Acho que deveria ter alguma coisa [...].

Infere-se, que o Art. 96 mencionado acima abre brechas para distintas interpretações, pois não deixa claro os critérios de avaliação no que diz respeito ao nível de habilitação, condição e sucesso dos educandos na alfabetização e no letramento, do mesmo modo, alude que está de acordo com a regulamentação própria na Proposta de Alfabetização e Letramento elaborada pela Secretaria de Educação. No entanto, observa-se, que no documento analisado não consta maiores informações sobre a gratificação.

Ao mesmo tempo, reflete-se que o prêmio pode ser compreendido como algo meritocrático, ou seja, algo que depende do mérito das professoras e consequentemente do sucesso dos estudantes para que as docentes o recebam. Nesse sentido, Gésica ${ }^{P 3}$ continua sua narrativa expondo, "o professor não precisa provar por $A+B$ que ele está alfabetizando, ou que ele é um professor, ou que ele está, vamos dizer assim... que tem que fazer projeto pra ganhar esse prêmio [...]. Além do mais, a professora participante supracitada expõe ainda, "o professor alfabetizador, está bem escasso! É uma coisa assim, que está bem no limite né, o município de Brusque é um! [...]. ${ }^{\mathrm{P} 3}$ "

Ainda com relação às formações propiciadas pelo município, Gésica ${ }^{\mathrm{P3}}$ reflete sobre as mudanças ocasionadas com a implementação da BNCC e relembra "eles até, passam uma demanda de formações né... igual a BNCC, vamos dar o exemplo da BNCC: eles nem sabiam, eles mesmos estavam muito confusos... então... eles têm que ter mais esse vínculo né, ter mais conhecimento entre eles mesmos pra passar algo pra gente né! ! ${ }^{P{ }^{\prime \prime}}$ Com relação à BNCC, de acordo com a Resolução do CNE/CP no 2, de 22 de dezembro de 2017, mais precisamente no Art. 15 do capítulo $V$ dispõe que "as instituições ou redes de ensino podem, de imediato, alinhar seus currículos e propostas pedagógicas à BNCC [...]. A adequação dos currículos à BNCC deve ser efetivada preferencialmente até 2019 e no máximo, até início do ano letivo de 2020" (BRASIL, 2017, p. 11). Desse modo, pela narrativa da professora Gésica ${ }^{\mathrm{P}}$, é visível que os municípios também tiveram que criar estratégias para implementar o documento nas escolas e dialogar com os professores sobre as mudanças preconizadas com sua implementação, entretanto, tal diálogo necessitaria ser mais próximo das escolas e dos professores, para que ambos pudessem dialogar sobre as mudanças advindas com a BNCC e ao mesmo tempo, pudessem refletir a respeito de tais mudanças, pois como advertiu Nóvoa (2009, p. 67), é urgente pensar-se num espaço público da educação que chama "os professores a uma 
intervenção política, a uma participação nos debates sociais e culturais [...]."

Para finalizar esta reflexão, expõe-se ao leitor que na categoria de análise a seguir discorre-se acerca das marcas positivas na relação que se estabelece entre família e escola. Marcas essas, que se fizeram presentes nas narrativas das professoras participantes desta pesquisa.

\section{MARCAS POSITIVAS NA RELAÇÃO FAMÍLIA E ESCOLA: EU SEMPRE TIVE CONVERSAS FRANCAS E SINCERAS}

Inicia-se esta categoria, com a narrativa da professora Claudia ${ }^{\mathrm{P} 2}$, quando ela expõe: "eu sempre tive o carinho dos pais, porque a minha relação com a família sempre foi muito boa, eu sempre tive conversas francas e sincera, nunca fui de tampar o sal com a peneira, então: "meu filho tem dificuldade nisso? Tem! Ele conversa? Conversa!

Na narrativa da professora Claudia ${ }^{\mathrm{P}}$, observa-se a importância do diálogo e do relacionamento franco entre a família e a escola, para que juntos possam contribuir para potencializar o avanço das crianças no processo de alfabetização. A esse respeito, Nóvoa (2009, p. 67) já nos atentou que a escola precisa comunicar-se com o exterior, ou seja, primeiramente, compreende-se que com a comunidade em que ela está inserida, pois com frequência, "os professores explicam mal o seu trabalho, conduzindo a enormes equívocos". No entanto, observa-se que tal comunicação se faz presente na relação que a professora Claudia ${ }^{P 2}$ estabelece com as famílias. Contudo, para que isso ocorra, as famílias precisam estar cientes do trabalho pedagógico que o professor realiza no cotidiano da sala de aula, uma vez que, "falar de escola e cidadania é prestar contas do que foi (e do que não foi) realizado na escola, é compreender que nada será conseguido se a sociedade não apoiar o trabalho escolar", o trabalho dos professores (NÓVOA, 2009, p. 67). Sendo assim, Claudia ${ }^{\mathrm{P} 2}$, narra ainda que os "pais, famílias $e$ as escolas devem andar de braços dados sempre e todos os dias! Isso na primeira reunião eu já falo com os pais, então, eles ficam conscientes quanto a isso né ! $?^{22 "}$

Claudia $^{\mathrm{P2}}$ ao continuar sua narrativa, reflete que não é possível transferir o papel da escola para os familiares, pois para alfabetizar são necessários saberes específicos, não sendo plausível que tal especificidade seja transferida para a família. Essa afirmação pode ser visualizada na narrativa da professora Claudia ${ }^{\mathrm{P} 2}$, quando ela expõe, "tem a reunião de pais, na primeira reunião de pais eu já digo: pessoal, não quero que ensinem letra cursiva para os filhos [...]. Eu já chego, eu já falo para os pais como é que é meu método, como é que eu trabalho, o que eles devem auxiliar, o que eles não devem auxiliar, e aí, isso tudo traz essa segurança para os pais $^{\text {P2" }}$.

Expõe-se ao leitor que na narrativa da professora já mencionada ${ }^{\mathrm{P} 2}$, torna-se evidente, que quando os pais se sentem seguros e confiam no trabalho pedagógico das professoras, a relação que se estabelece é de compartilhamento mútuo, pois ambos contribuem na aprendizagem e no desenvolvimento das crianças. Do mesmo modo, essa segurança só é possível, porque a professora Claudia ${ }^{\mathrm{P2}}$ estabelece uma relação de confiança e demonstra possuir conhecimentos a respeito do "que fazer" para alfabetizar as crianças. Esse conhecimento é denominado por Shulman (2014) como o conhecimento pedagógico do conteúdo, ou seja, o conhecimento da matéria e o conhecimento de como ensinar.

Claudia $^{\mathrm{P} 2}$, continua sua narrativa expondo as "marcas positivas" do reconhecimento e a valorização da família no trabalho docente, ao narrar: "eu digo assim, a valorização muitas vezes não vem: ah, porque a Prô ganhou um presente (é valorizada), não. Às vezes, até com palavras, com gestos de agradecimentos que ao longo desses anos, podes ter certeza, foram muitos tá, foram muitos! Pais que choraram no meu ombro, agradeceram por tudo que eu fiz, isso não tem preço né?"

Nóvoa (1999) contribui com uma reflexão a respeito do estatuto social e econômico dos professores, quando reflete que primeiramente, tem-se a impressão de que a imagem social e a condição econômica dos professores se encontram em um período de degradação, sentimento confirmado por alguns discursos de sindicatos e organizações estatais, entretanto, "cada vez que a análise é mais fina os resultados são menos concludentes e a profissão docente continua a revelar facetas atrativas" (NÓVOA, 1999, p. 29), no entanto, "por vezes alimenta-se publicamente a ideia de que ensinar é muito simples, contribuindo assim, para um desprestígio da profissão (NÓVOA, 2009, p. 33). Observa-se que se faz presente na narrativa da professora Claudia $^{\mathrm{P2}}$ a valorização das famílias 
acerca da sua atuação docente, e que apesar de discursos contrários, a profissão continua a ser valorizada, como nos atentou Nóvoa (2009).

Igualmente, a professora Claudinice ${ }^{\mathrm{P} 6}$, ao relembrar seu percurso profissional, expõe: "durante os anos, acredito que marcas positivas foram muitas assim, de pais, de apoio de direção, de coordenação, da própria escola sabe, de ... incentivar, de acreditar na gente, de dizer que a gente é, era uma ótima professora ${ }^{P G \prime}$. Ao mesmo tempo, a professora Rute ${ }^{P 4}$ também relembra como algo positivo "os seus alunos como colegas de trabalho ou mesmo os pais trazendo seus filhos e dizendo: essa filho, já foi minha professora $^{\text {P4" }}$.

Do mesmo modo, Gésica, ${ }^{\mathrm{P3}}$ expõe uma situação relacionada com o reconhecimento dos pais, que deixou marcas positivas em sua vida, ela narra, "Foi um domingo à noite, e teve uma mãe assim que me mandou uma mensagem [...] via Messenger, do Facebook ... e ela disse: Professora, eu queria muito te agradecer e hoje mais do que nunca, eu vou rezar muito por ti! Estávamos na igreja, estávamos na missa e o meu filho leu o que estava escrito no anúncio assim ... parece que era a Nossa Senhora Aparecida, era uma frase, bem complexa até. Aí, ela disse: eu quero muito te agradecer! Então, esse prazer assim, dos pais te darem esse valor, te procurar e dizer: "Meu, muito obrigado!" Isso aí, não tem... não há dinheiro que pague! Tu chega assim... eu me emociono, porque é um retorno que eles têm $n e ́ !^{P 3 \prime \prime}$

Expõe-se ao leitor que apesar de existirem marcas positivas narradas pelas professoras na relação família e escola, na narrativa das professoras também foi possível observar algumas dificuldades/marcas negativas provenientes dessa relação, que poderão ser evidenciadas na categoria de análise a seguir.

\section{MARCAS NEGATIVAS NA RELAÇÃO FAMÍLIA E ESCOLA: O DESAFIO É COM OS PAIS E TRABALHAR COM AS CRIANÇAS ESPECIAIS}

Nesta categoria análise, discorre-se a respeito da relação família e escola e os desafios que perpassam as dificuldades vivenciadas por elas, no que diz respeito ao processo de inclusão das crianças que apresentam distúrbios de desenvolvimento e aprendizagem bem como, os momentos em que os pais demonstraram não confiar no trabalho desenvolvido pelas professoras.
Para tal, inicia-se a presente categoria com a narrativa da professora Gésica ${ }^{\mathrm{P} 3}$, quando ela expõe: "o maior desafio é com os pais. Porque assim, tem muitos pais né, que não aceitam às vezes o professor... é aquela coisa: Quando eles te veem dizem assim: poxa, mas aquela ali é muito novinha né, aquela ali não vai dar conta! Muitos pais não aceitam $[. . .]^{P 3 \prime \prime}$.

Oliveira e Marinho-Araújo refletem que apesar de a família e a escola serem os principais contextos de desenvolvimento humano, poucas pesquisas têm-se dedicado a compreender sistematicamente a relação existente entre ambas. Desse modo, se, por um lado, a importância da família e da escola como contextos privilegiados de desenvolvimento está consolidada em virtude dos estudos da psicologia da família e da psicologia do desenvolvimento, por outro, os aspectos que compõem e interferem na relação entre estes dois contextos, sejam como barreiras à colaboração ou contribuindo para a sua promoção, ainda não estão satisfatoriamente estabelecidos. Advém, então, que um dos reflexos do baixo desenvolvimento de pesquisas científicas voltadas à intersecção que se estabelece diariamente na relação família e escola é a ausência de publicações suficientemente atuais nesta temática.

Claudinice ${ }^{\mathrm{P} 6}$, ao rememorar essa relação, observa nos momentos difíceis, a contribuição da direção e da coordenação pedagógica da escola que a "defendia" "diante de pais que vinham querendo desacreditar do trabalho da gente, então a escola, sempre assim foi uma grande aliada durante toda a trajetória, enquanto as direções que passaram por ela ${ }^{P 6 "}$.

O papel da gestão escolar conforme observado na narrativa da professora

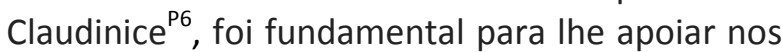
momentos nos quais os pais por ventura demonstravam insegurança com relação ao trabalho desenvolvido pela professora. A esse respeito, Nóvoa (2009) elucida que a complexidade do trabalho escolar exige um aprofundamento das equipes pedagógicas e que a formação dos professores ganharia muito se fosse organizada em torno de discussões, situações reais de insucesso escolar, de problemas escolares que os docentes enfrentam ou de programas de ação educativa, contribuindo para o compartilhamento de saberes dentro da profissão, numa dimensão que rompa com a individualidade da docência (NÓVOA, 2009). 
Elucida-se que com relação ao processo de inclusão das crianças que apresentam distúrbios de desenvolvimento e aprendizagem, as narrativas das professoras alfabetizadoras evidenciam algumas dificuldades que perpassam situações vivenciadas na sala de aula e a não aceitação, por vezes, dos familiares em buscar auxílio para essas crianças, pois, muitos pais se negam a aceitar que seus filhos necessitam de um atendimento educacional especializado.

Desse modo, Nice ${ }^{\mathrm{P}}$, ao rememorar as dificuldades vivenciadas na sala de aula, relembra uma marca negativa de seu percurso profissional quando expõe: "ele tinha déficit de atenção, mas assim, nunca tinha sido diagnosticado nada, mas a gente percebia né. Então, assim, muito, muito complicado! E eu sempre tentando puxar essa criança e conversando com a mãe, e coisa... aí, um dia, ela veio e disse: Ô Prô, o fulano né, vou chamar de João, João está lendo Prô! Você acredita que ele está lendo! Eu pensei: ai meu Deus, o que aconteceu? Porque ele não estava lendo. Aí, a mãe relatou ${ }^{P}$... "depois você mostra tá João, pra Professora que você está lendo, que você sabe ler!" Aí, ele pegou um livro, um livrinho de história e começou a ler a história. "Ah, era uma vez... mas ele estava lendo era uma vez e já estava na terceira ou na quarta folha, e assim, ele lia e ele sabia o livro, o livro era um livro pequeno, ele sabia o livro de cor, mas não sabia ler. Tanto é, que ele estava numa folha e estava lendo outra folha. Então, o que eu achei de muito negativo assim ó: a mãe, ensinou esse filho a mentir, porque ela fez o filho decorar e... eu não sei se o filho percebeu naquele momento que a mãe estava mentindo, não sei, tomara que não, mas... ela sabia que ele não estava lendo. Ela sabia, porque ela fez ele decorar, ela contou por certo, 10, 20, 30 vezes e fez ele decorar, pra dizer que ele estava lendo. Então, isso aí, eu nunca esqueço, eu nunca esqueço esse detalhe! ${ }^{\text {P1" }}$

$\mathrm{Na}$ narrativa da professora $\mathrm{Nice}^{\mathrm{P} 1}$, observa-se a resistência da mãe em aceitar a opinião da professora sobre o processo de ensino e aprendizagem de seu filho, pois de acordo com a professora, ele tinha déficit de atenção e ela vinha dialogando com a mãe sobre 0 comportamento apresentado pela criança. A esse respeito, Portela e Almeida (2009) salientam que, a família e a escola ocupam um lugar imprescindível e indissociável na formação do indivíduo e que, apesar de possuírem características e possibilidades diferenciadas, com frequência essas instituições se superpõem e se complementam, de tal modo que não se pode abordar o desenvolvimento do indivíduo e a sua educação sem tê-las em conta. Desse modo, ambas precisam caminhar juntas e, assim como a mãe necessitaria ter a sensibilidade para ouvir as orientações da professora, a professora também careceria de compreender a dificuldade da mãe em lidar com a situação apresentada, pois, conforme observam Falkenback, Drexsler e Werler (2008) em uma sociedade de comportamentos pragmáticos, de rendimento e produtividade, a ideia que perpassa é a de uma criança que irá ser passada para trás, que irá sofrer, que não poderá desenvolver comportamentos de autonomia. Assim, os pais desenvolvem uma preocupação que os atinge profundamente.

Entretanto, mais do que a mãe não aceitar a opinião da professora, o que a deixou chateada, conforme foi possível observar em sua narrativa, foi o fato de a mesma ter coagido a criança a mentir dizendo que ela já "sabia ler". Portela e Almeida (2009, p. 150), nesse sentido observam que:

[...] especialistas de
diversas áreas -
pedagogos, psicólogos,
médicos, sociólogos, entre
outros - comprovam
como os comportamentos
familiares constituem
premissas básicas no
desenvolvimentor da
personalidade ro do
indivíduo, a começar pela
aquisição de formas
simples de
comportamento, que
passam a formas mais
complexas, como as
normas e os valores, até
chegar à transmissão da
herança cultural própria
tanto da família como da
sociedade.

Contudo, ressalta-se que objetivo aqui não é fazer "juízo de valor" e sim, refletir acerca do comportamento apresentado pela mãe, pois igualmente, compreende-se que naquele momento ela poderia não estar sabendo lidar com a situação ocorrida e até mesmo poderia estar sentindo "medo" da não aceitação de seu filho pelos demais colegas da classe pelo fato de - mesmo não "saber ler". Mais adiante, a professora $^{\mathrm{P} 1}$ já mencionada, complementa sua 
narrativa expondo "depois, mais pra frente, ele foi encaminhado, porque ali ela não aceitava ainda que ele tinha alguns déficits né, ele foi encaminhado e realmente foi diagnosticado como déficit de atenção e outros problemas ali. Então isso ali, foi uma marca muito negativa ${ }^{P 1 "}$. Desse modo, é possível aludir que, posteriormente, a mãe, igualmente percebeu a necessidade de procurar auxílio de um outro profissional para que juntamente com a escola ambos contribuíssem para potencializar $\mathrm{o}$ desenvolvimento de seu filho. Trata-se então, conforme observado por Portela e Almeida ( $p$. 156-157):

[...] de buscar fazer com que a família se perceba como participante do processo educacional, uma vez que ela pode contribuir com aspectos fundamentais durante 0 tempo que a criança passa sob sua influência, sem, no entanto, ter a pretensão de substituir o lugar da escola. É preciso rever a concepção que coloca a escola em posição de cobrança, e a família em posição de culpada, ou cobrada. Assim, a família funciona como um elemento estratégico no processo de escolarização dos alunos que não apresentam um resultado esperado.

A professora Claudia $^{\mathrm{P} 2}$ também expõe uma situação na qual o pai apresenta resistência para aceitar que o filho necessita de um apoio maior no processo de alfabetização, ela narra "as principais dificuldades são com as crianças que tem problema, que a gente sabe, é nítido, e que os pais não buscam ajuda ... [...] Até, esse ano eu tive uma reunião com um pai, o menino é nítido que ele é autista, mas o pai não aceita, ele disse: "eu não quero escutar esse laudo", ele foi bem nítido assim sabe, ele foi bem assim: "eu não quero saber que ele é autista. ${ }^{\text {P2" }}$

Novamente, na narrativa da professora mencionada ${ }^{\mathrm{P}}$, observa-se a resistência da família em aceitar que por vezes, há a necessidade de encaminhar a criança a um profissional da saúde especializado em diagnosticar distúrbios de desenvolvimento e aprendizagem. Falkenback,
Drexsler e Werler (2008, p. 2069) indicam que "a cultura de negação é superior a qualquer possibilidade, assim o sofrimento é agudo naqueles que convivem com essa experiência". No entanto, quando os pais aceitam a opinião das professoras e demonstram-se dispostos a buscar apoio de um profissional especializado, isso pode fazer muita diferença no desenvolvimento da criança e contribuir para potencializar, inclusive, o trabalho da professora em sala de aula que ao saber que determinada criança possui autismo, como narrado pela professora Claudia ${ }^{\mathrm{P2}}$ ou déficit de atenção, mencionado pela professora Nice ${ }^{\mathrm{P} 1}$, poderá receber um apoio diferenciado e até mesmo um monitor ${ }^{6}$ escolar para Ihe auxiliar nas atividades da sala de aula.

Já a professora Claudinice ${ }^{\mathrm{P} 6}$, ao rememorar seu percurso profissional, igualmente expõe que "os maiores desafios, eu acho que, é... é quando a gente encontra, eu digo, não... desafio... eu acho que é aquela criança que tem alguma dificuldade por algum motivo, e às vezes nem é de aprendizagem, mas algo a mais que a gente não consegue identificar e vai por várias linhas, vários caminhos até a gente conseguir uma pontinha assim ... que tu consegue chegar lá e alcançar... eu digo assim, saber o que fazer por ela pra poder ajudá-la! P6" Igualmente, a professora Rute ${ }^{\mathrm{P} 4}$ ao narrar os maiores desafios vivenciados em seu percurso profissional docente, expõe: "o meu maior desafio foi ter recebido um aluno com transtorno opositor forte e além disso sem educação. E ter forças para que os demais alunos tivessem disciplina $e$ não perdessem o foco ${ }^{\text {P4" }}$.

Na narrativa da professora Claudinice ${ }^{\mathrm{P} 2} \mathrm{e}$ da professora Rute $^{\mathrm{P4}}$ parece implícita a importância dos momentos de formação continuada, sobretudo, de uma formação centrada na escola, para que ambos os profissionais que lá atuam possam entre si, buscar estratégias por meio do diálogo e do compartilhamento de saberes, tendo em vista a superação das dificuldades que se fazem presentes no cotidiano escolar, pois a formação inicial não consegue suprir todas as necessidades encontradas pelos professores no decorrer de seu percurso profissional, inclusive Vaillant e Marcelo (2015) nos atentam com relação a isso, quando expõem que a formação inicial é o primeiro marco de um desenvolvimento

\footnotetext{
${ }^{6}$ Ou ainda, receber o apoio em sala de aula de um segundo professor.
} 
profissional que precisa ser contínuo e, portanto, é um processo que ocorre durante toda a vida do docente. Nessa direção, Imbernón (2011) observa, que esse tipo de formação envolve todas as estratégias empregadas em conjunto pelos professores e formadores com a finalidade de responder às necessidades definidas da escola e elevar a qualidade do ensino e aprendizagem dos estudantes.

Entretanto, mais do que propiciar formação continuada às professoras, é necessário ter uma estrutura e recursos adequados para atender e incluir todas as crianças no processo educacional, pois, sem isso, a formação continuada não dará conta de atender às especificidades das crianças e superar os desafios vivenciados pelas professoras.

Expõe-se ao leitor que na próxima categoria de análise discorre-se a respeito das marcas positivas, "das maiores alegrias", que as professoras alfabetizadoras narraram vivenciar ao serem alfabetizadoras.

\section{MARCAS POSITIVAS NA RELAÇÃO COM AS CRIANÇAS: O MEU MAIOR PRAZER É VER E ESCUTAR MEUS ALUNOS LENDO PARA MIM}

Nesta categoria de análise, elucida-se a respeito das marcas positivas que as professoras alfabetizadoras narraram vivenciar na profissão. Primeiramente, observa-se que as marcas narradas nesta categoria permearam nas narrativas de todas as seis professoras alfabetizadoras participantes desta pesquisa. Tais marcas, foram expostas por elas como "as maiores alegrias" vivenciadas na profissão, e dentre essas marcas, destaca-se: "a aprendizagem e desenvolvimento das crianças diante das atividades propostas e consequentemente quando elas começam a ler e a escrever ${ }^{p "}$. Desse modo, inicia-se esta categoria com a narrativa da professora Rute ${ }^{\mathrm{P} 4}$, quando ela expõe: "o meu maior prazer é ver e escutar meus alunos lendo para mim ${ }^{P 4 "}$, do mesmo modo, a professora Claudinice ${ }^{\mathrm{P} 6}$ expõe: "o meu maior prazer é a criança conseguir ler, a criança conseguir escrever né, perceber que ela já está conseguindo, na verdade eu quero dizer assim: que ela já está percebendo que ela consegue ler, que ela já consegue escrever, que ela é capaz, capaz! ${ }^{P G "}$ Igualmente, a professora Nice ${ }^{\mathrm{P}}$, observa que a sua maior alegria "é quando chega ... nem precisa chegar ao final do ano, mas a gente diz final do ano, a maioria pelo menos já está lendo né. Mas, quando, de repente, lá no meio tu vê que uma criança está lendo [...] então, esse momento, é o momento mágico! Todos os momentos que você descobre que a criança está conseguindo ler, está alfabetizada, é um momento mágico, então, é um dos momentos... é vitória! Cada criança que se alfabetiza, é uma vitória para o professor alfabetizador ${ }^{\text {P1" }}$.

Claudia $^{\mathrm{P} 2}$ ao narrar, relembra um diálogo com suas crianças a respeito da aprendizagem da leitura, ela expõe: "olha pra Prô, vocês querem ler? Queremos Prô! Então, depende de vocês, não é da Prô, é de vocês! Se vocês querem vocês têm que ter vontade, tem que dizer "eu quero, eu consigo". Isso eu coloco bem pra eles, esse lado, que eles são inteligentes, que eles são capazes $e$ isso é muito importante pra criança tá, valorizar ela, né! [...], "ah, ele não sabe ler!" Não, todos sabem ler. Quando eu falo em todos, todos sabem ler, só que cada um sabe ler da sua forma, né [...] É que às vezes vieram de uma outra escola, vieram de um outro estado, aí era diferente os métodos, as estratégias $[. . .]^{p 2}$."

$\mathrm{Na}$ narrativa da professora Claudia ${ }^{\mathrm{P} 2}$, se faz presente a diversidade cultural em uma sala de aula e os diferentes saberes provenientes da cultura que cada criança traz consigo. Soares (2016) observa que a aprendizagem inicial da língua escrita sofre influência desses fatores tanto em relação às características pessoais quanto em relação às experiências de aprendizagens que antecedem à alfabetização de cada criança. Do mesmo modo, "mais complexa se torna a situação de ensino e aprendizagem se se considera que ela ocorre inserida em determinado contexto escolar e em determinada comunidade" (SOARES, 2016, p. 51).

Ao observar a narrativa da professora já mencionada $^{\mathrm{P2}}$, percebe-se presente essa preocupação, esse "cuidado" por assim dizer, com as especificidades de cada criança, visto que ela demonstra encorajar suas crianças, quando afirma que, independente da cultura e da situação que cada criança se encontra: "todos sabem ler, só que cada um sabe ler da sua forma P2",

Do mesmo modo, a professora Cilene ${ }^{\mathrm{p5}}$ observa que enquanto professora alfabetizadora, para ela era algo muito gratificante "ver as descobertas, as primeiras leituras, as primeiras escritas e todo o caminho que elas percorrem é

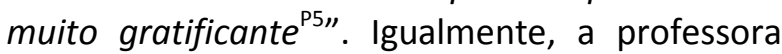
Gésica" ${ }^{\mathrm{P} 3}$, narra: "minha maior alegria é quando vejo que os alunos conseguem assimilar o 
conteúdo passado e também estão lendo. Isso é uma alegria e satisfação ${ }^{\text {P3" }}$.

Nóvoa (2009) expõe que a aprendizagem não é um processo linear, mas que possui várias facetas, e que promover essa aprendizagem implica aos professores compreenderem a importância da relação ao saber, instaurando novas formas de se trabalhar na escola, além disso, Soares (2016) observa que são muitas as situações que podem facilitar 'ou não', o processo inicial de alfabetização das crianças, inclusive as peculiaridades presente nas alfabetizadoras e nas crianças e na relação estabelecida entre ambos.

\section{CONCLUSÕES}

$\mathrm{Na}$ análise das marcas positivas e negativas que seis professoras alfabetizadoras experientes vivenciaram ao longo de suas trajetórias docentes, foi possível desvelar marcas positivas relacionadas com a formação continuada, com cursos oferecidos pelo município por meio do governo federal, mas também algumas lacunas, caracterizando-se como "marcas negativas" dessa formação que por vezes, distancia-se das reais necessidades apresentadas pelas alfabetizadoras, indo na contramão de uma "formação centrada na escola", apontada pelos autores como Imbernón (2011), Vaillant e Marcelo (2015) e Nóvoa (1992, 2009) como um tipo de formação que contribui para uma construção efetiva e colaborativa, com vistas a atender as reais necessidades dos professores.

Espera-se, portanto, que as reflexões suscitadas nesta pesquisa, possam contribuir para uma mudança nas formações continuadas oferecidas aos professores, sobretudo aos professores alfabetizadores, tendo em vista ainda a especificidade da função e dos saberes específicos necessários para alfabetizar.

Também evidenciaram-se as marcas positivas e negativas da relação família e escola, sendo visível que quando os pais sentem confiança no trabalho desenvolvido pelas professoras, "todos ganham", professores, família e principalmente as crianças. Por outro lado, quando os pais não sentem confiança, criase uma lacuna nessa relação, dificultando o trabalho pedagógico realizado pelas professoras. Diante de tais constatações, as pesquisadoras compreendem, que o diálogo é fundamental para o estabelecimento de uma relação sólida e de confiança entre ambas as partes. Sendo imprescindível, portanto, como nos atentou Nóvoa (2009), abrir as escolas para a comunidade, para que conheçam a fundo o trabalho realizado pelos docentes cotidianamente nas escolas.

Ressalta-se que uma "marca" positiva presente em todas as narrativas das professoras alfabetizadoras, diz respeito à aprendizagem da leitura e da escrita pelas crianças. Tal aprendizagem, exige dos docentes "saberes e fazeres" específicos da alfabetização, pois, conforme expõe Soares (2014),

[...] é preciso reconhecer que SABERES sobre a alfabetização se constroem não só por teorias, mas também se constroem em decorrência dos FAZERES cotidianos dos que alfabetizam: há SABERES teóricos e há os SABERES da prática; dessa maneira, há FAZERES propostos por teorias, e há os FAZERES propostos pelas práticas, aqueles FAZERES que efetivamente se revelam possíveis e condizentes com as circunstâncias reais em que se desenvolve o processo de alfabetização, sob condições as mais variadas, por participantes específicos e para participantes específicos (SOARES, 2014, p. 31).

Tais "saberes e fazeres", ficaram evidentes nas narrativas das seis professoras alfabetizadoras experientes participantes desta pesquisa.

Igualmente, também permaneceu em evidência algumas resistências e dificuldades relacionadas à inclusão e o processo de alfabetização das crianças que apresentam distúrbios de desenvolvimento e aprendizagem, pois, com frequência, muitos pais não aceitam as orientações das professoras em buscar auxílio educacional especializado, dificultando o trabalho realizado em sala de aula. Nesse sentido, torna-se urgente romper com a estigma de que todas as crianças são iguais, quando na verdade, cada criança é única e merece ser respeitada e valorizada em sua singularidade. 
Para finalizar esta conclusão que não é finita, espera-se poder contribuir para a formação de professores, ao valorizar as narrativas das alfabetizadoras experientes e, sobretudo, contribuir com os professores alfabetizadores iniciantes que, ao refletirem acerca das marcas positivas e negativas narradas pelas alfabetizadoras, poderão servir de inspiração para escolher a alfabetização como um local de construção de sua profissionalidade docente. Pois, como buscou-se elucidar nesta pesquisa, a construção de uma profissionalidade é um processo contínuo, que não se extenua na formação inicial, mas ocorre ao longo da vida, nas diferentes fases da carreira docente, conforme exposto por Vaillant e Marcelo (2015).

Seguindo esta reflexão, observa-se ainda as dificuldades comumente vivenciadas no início da docência. Nesse viés, Vaillant e Marcelo (2012) observam que as políticas associadas ao desenvolvimento profissional docente necessitam prestar atenção aos dispositivos de apoio para aqueles que iniciam na docência. Essa é uma das fases de aprender o ofício de ensinar que metodicamente foi esquecida. Uma etapa na qual as dúvidas, as inseguranças e a ansiedade por introduzir-se na prática acumulam-se e residem sem boa vizinhança. É um período importante na trajetória do docente que se refere à obtenção de um adequado conhecimento e competência profissional em um breve período de tempo e, em geral, é um período de solidão para os docentes iniciantes. Deste modo, reforça a posição das pesquisadoras nesta pesquisa, pois, por meio das narrativas das professoras alfabetizadoras experientes, buscouse desvelar as marcas positivas e negativas vivenciadas pelas alfabetizadoras com vistas a contribuir por meio dessa experiência, com os professores alfabetizadores iniciantes.

Sem dúvida, as dificuldades se fizeram presentes nas marcas negativas, mas que elas sirvam, portanto, de reflexão para que haja mudanças na formação continuada de professores. Ao mesmo tempo, as marcas positivas foram muitas. Desse modo, as pesquisadoras que aqui escrevem, fazem votos de que as narrativas elucidadas possam inspirar professores alfabetizadores iniciantes a permanecerem na docência, reforçando o trabalho coletivo construído dentro da profissão.

\section{REFERÊNCIAS}

BRASIL. Estado de calamidade pública 18 de março de 2020. Diário Oficial da União. Brasília, 20 mar. 2020b. Seção 1, p. 1. Disponível em: https://www.conjur.com.br/dl/decretolegislativo-2020-coronavirus.pdf. Acesso em: 21 maio 2020.

BRASIL. Portaria no 867, de 4 de julho de 2012. Diário Oficial da União. Brasília, 2012. Disponível em: https://www.normas.gov.br/materia//asset_publisher/NebW5rLVWyej/content/id/237 45400. Acesso em 12 nov. 2019

BRASIL. Portaria no 867. Diário Oficial da União. Brasília, 4 jul. 2012. Disponível em: http://download.inep.gov.br/educacao_basica/pr ovinha_brasil/legislacao/2013/portaria_n867_4ju Iho2012_provinha_brasil.pdf. Acesso em 12 nov. 2019.

BRUSQUE. Estatuto do Magistério Público Municipal de Brusque. 2009. Disponível em: https://leismunicipais.com.br/pdf/Leicomplementar-146-2009-Brusque-SCconsolidada-[24-03-2016]. Acesso em: 26 maio. 2020.

BRASIL. Portaria no 343, de 17 de março de 2020. Brasília, 2020a. Disponível em: https://www.in.gov.br/en/web/dou/-/portaria-n343-de-17-de-marco-de-2020-248564376. Acesso em: 21 maio. 2020.

\section{BRASIL. Resolução CNE/CP № 2, 22 de dezembro} de 2017. Brasília, 2017. Disponível em: http://portal.mec.gov.br/index.php?option=com _docman\&view=download\&alias=79631-rcp00217-pdf\&category_slug=dezembro-2017pdf\&Itemid=30192. Acesso em: 08 jun. 2020.

CARLOS, M. Desenvolvimento Profissional Docente: passado e futuro. Sísifo: Revista de Ciências da Educação, v.8, p. 7-22, jan./abr. 2009. Disponível em: http://www.unitau.br/files/arquivos/category_1/ MARCELO__Desenvolvimento_Profissional_Doc ente_passado_e_futuro_1386180263. Acesso em: 03 agos. 2020 .

FALKENBACH, A. P.; DREXSLER, G.; WERLER, V. A relação mãe/criança com deficiência: sentimentos e experiências. Ciênc. saúde coletiva [online]., v.13, p.2065-2073, 2008. Disponível 
em: https://www.scielo.br/. Acesso em: 30 jun. 2020. DOI:10.1590/S1413-81232008000900011

FERRAROTTI, F. Sobre a autonomia do método biográfico. In: NÓVOA, António; FINGER, Matthias (Org.). $O$ método (auto)biográfico e a formação. Natal, RN: EDUFRN: São Paulo: Paulus, 2010. p. 31-58.

GARCIA. C. M. Formação de professores para uma mudança educativa. 2. ed. Porto Editora: Portugal, 1999.

IMBERNÓN. F. Formação continuada de professores. Porto Alegre: Artmed, 2010.

IMBERNÓN, F. Formação docente e profissional: formar-se para a mudança e a incerteza. 9. ed. São Paulo: Cortez, 2011.

MENEZES, E.T. de.; SANTOS, T. H dos. Profa (Programa de Formação de Professores Alfabetizadores). In: DICIONÁRIO Interativo da Educação Brasileira - Educabrasil. São Paulo: Midiamix, 2001. Disponível em: https://www.educabrasil.com.br/profaprograma-de-formacao-de-professoresalfabetizadores/. Acesso em: 04 fev. 2020.

MORAES, R.; GALIAZZI, M do C. Análise Textual Discursiva. 2. ed. rev. Ijuí: Ed. Unijuí, 2011.

NÓVOA, A (Org.). Os professores e a sua formação. Lisboa: Dom Quixote: Instituto de Inovação Educacional, 1992.

NÓVOA, A. (org.). Vidas de professores. 2. ed. Porto: Porto, 2000.

NÓVOA, A. Professores: imagens do futuro presente. Lisboa: Educa, 2009.

NÓvOA, A. A formação tem que passar por aqui: as histórias de vida no Projeto Prosalus. In: NÓVOA, António. FINGER, M. (Orgs.). O método (auto)biográfico e a formação. Natal, RN: EDUFRN: São Paulo: Paulus, 2010. p. 155-188.

NÓVOA, A. Os professores e sua formação num tempo de metamorfose da escola. Educação \& Realidade, Porto Alegre, v. 44 n. 3, p. 1-15, 2019. Disponível em: https://www.scielo.br/scielo.php?script=sci artte xt\&pid=S2175-62362019000300402\&tlng=pt.
Acesso em: 04 fev. 2020 DOl:10.1590/2175$\underline{623684910}$

OLIVEIRA, C. B. E de.; MARINHO-ARAÚJO, C. M. A relação família-escola: intersecções e desafios. Estudos de Psicologia, Campinas, p. 99-108, jan/ mar, 2010. Disponível em: https://www.scielo.br/scielo.php?script=sci artte xt\&pid=S0103-

166X2010000100012\&lng=pt\&tlng=pt. Acesso em: 04 fev. 2020. DOl:10.1590/S0103$\underline{166 \times 2010000100012}$

PORTELA, C. P. J.; ALMEIDA, C. V. P. J. Família e escolar: como essa parceria pode favorecer crianças com necessidades educativas especiais. In: DÍAZ, F., et al., (Orgs). Educação inclusiva, deficiência e contexto social: questões contemporâneas [online]. Salvador: EDUFBA, 2009, p. 148-159.

PRADO, G do V. T.; SOLIGO, R. Memorial de Formação - quando as memórias narram a história da formação. In: PRADO, G do V. T.; SOLIGO, R (Orgs.). Porque escrever é fazer história: revelações, subversões, superações. Campinas, SP: Editora Alínea, 2007. p. 45-60.

SHULMAN, L. S. Conhecimento e ensino: fundamentos para a nova reforma. Cadernos Cenpec, São Paulo. v. 4, n. 2, p. 196-229, dez. $2014 . \quad$ Disponível em: http://cadernos.cenpec.org.br/cadernos/index.p $\mathrm{hp} /$ cadernos/article/view/293/297. Acesso em: 27 ago. 2019. DOI:10.18676/2237-998322014293

SOARES. M. Alfabetização: a questão dos métodos. São Paulo: Contexto, 2016.

SOARES, M. Alfabetização: o saber, o fazer, o querer. In: MORTATTI, Maria do Rosário Longo. FRADE, Isabel Cristina Alves da Silva (Orgs.). A alfabetização e seus sentidos. Marília: Oficina Universitária; São Paulo: Editora Unesp, 2014. p. 27-38.

VAILLANT, D.; MARCELO, C. Ensinando a ensinar: as quatro etapas de uma aprendizagem. Curitiba: Ed. UTFPR, 2012.

VAILLANT, D.; MARCELO, C. El ABC y D de La Formación Docente. Madrid - Espanã: Narcea, S.A. de Ediciones, 2015. 